\title{
Liver copper concentration in cattle and herbage copper, sulphur, iron and molybdenum concentrations on commercial farms in the Wairoa region
}

\author{
A.J. LITHERLAND ${ }^{1}$, C.J. KORTE ${ }^{2}$, A. DOWLING ${ }^{3}$, D. $\mathrm{SMITH}^{1}$, C. MOFFAT ${ }^{1}, \mathrm{~J}_{\text {. }} \mathrm{LEE}^{1}$ and \\ M.G. LAMBERT ${ }^{1}$ \\ ${ }^{1}$ AgResearch, Grasslands Research Centre, Palmerston North \\ ${ }^{2}$ AgResearch, Poukawa, Hastings \\ ${ }^{3}$ Wairoa Vet Services, Wairoa
}

\section{Abstract}

Seasonal changes in herbage elements $(\mathrm{Cu}, \mathrm{Mo}, \mathrm{S}$, $\mathrm{Fe}$ ), pasture growth, and soil moisture were measured and their relationships with liver $\mathrm{Cu}$ concentration in weaner heifers $(\mathrm{n}=10-12)$ and breeding cows $(n=10-12)$ were determined on 7 commercial farms in the Wairoa region. Liver biopsy samples were collected at 2 to 4 monthly intervals and herbage and soil moisture monthly from spring 1996 to spring 1998. Mean Mo concentration of herbage offered to cattle on the 7 farms ranged from 0.7 to $3.2 \mathrm{mg} \mathrm{Mo} / \mathrm{kgDM}$ and $\mathrm{Cu}$ herbage concentrations from 5.7 to $10.5 \mathrm{mg}$ $\mathrm{Cu} / \mathrm{kgDM}$. Mean concentrations of $\mathrm{Cu}$ in cattle livers ranged from 85 to $204 \mu \mathrm{mol} \mathrm{Cu} / \mathrm{kgFW}$ across farms. Herbage $\mathrm{Cu}, \mathrm{S}$ and $\mathrm{Fe}$ concentrations were highly seasonal with low levels in late springsummer and high levels in autumn and winter. In contrast, herbage Mo was less seasonal. There was a suggestion that variation in liver $\mathrm{Cu}$ across seasons was positively affected by increasing herbage $\mathrm{Cu}$ concentration and negatively affected by increasing herbage $\mathrm{S}$ concentration and unaffected by herbage Mo concentration. Over the two years $46 \%$ of non$\mathrm{Cu}$ supplemented cows and $32 \%$ of weaners had deficient $(<95 \mu \mathrm{mol} \mathrm{Cu} / \mathrm{kgFW})$ liver $\mathrm{Cu}$ levels but clinical signs of $\mathrm{Cu}$ deficiency were not observed. Weaner liver $\mathrm{Cu}$ concentrations were low in summer and autumn $(126 \mu \mathrm{mol} / \mathrm{kgFW})$ but repleted over the winter and spring seasons (195 and 237 $\mu \mathrm{mol} / \mathrm{kgFW}$ respectively). Cows had highest levels of liver $\mathrm{Cu}$ in summer $(147 \mu \mathrm{mol} / \mathrm{kgFW})$ but these fell steadily over winter to reach low $(62 \mu \mathrm{mol} \mathrm{Cu} /$ $\mathrm{kgFW})$ levels in spring before calving. The study supports the conclusion of Korte (1995) that in the Wairoa region herbage Mo may impair absorption of $\mathrm{Cu}$ in cattle grazing pasture with Mo levels as low as $0.5 \mathrm{mg} / \mathrm{kgDM}$, but once herbage Mo rises above $2 \mathrm{mg} / \mathrm{kgDM}$ then further reduction in $\mathrm{Cu}$ absorption is minimal.

Keywords: copper, cows, herbage composition, herbage minerals, liver, molybdenum, season, soil moisture, weaners

\section{Introduction}

Copper $(\mathrm{Cu})$ deficiencies are widespread in the New Zealand beef industry, particularly in the Wairoa region where $60-70 \%$ of breeding cows and $40 \%$ of ewes are routinely supplemented with $\mathrm{Cu}$. Copper deficiencies are not only associated with low $\mathrm{Cu}$ intakes, but more frequently are caused by dietary antagonists, such as molybdenum (Mo), sulphur (S) and iron (Fe) which impair the absorption and/or utilisation of $\mathrm{Cu}$ (Suttle \& McLauchlan 1976). In an earlier survey conducted on 100 farms in the Wairoa region, it was found that herbage Mo concentration was the main predictive factor associated with low liver $\mathrm{Cu}$ concentrations in lambs, weaner cattle and breeding cows (Korte et al. 1995). Further, this survey suggested that herbage Mo concentrations as low as $0.5 \mathrm{mg} \mathrm{Mo} / \mathrm{kg}$ DM reduced liver $\mathrm{Cu}$ concentrations in cattle. Previously it was thought that Mo only affected liver $\mathrm{Cu}$ concentrations at much higher ( $>3 \mathrm{mg} \mathrm{Mo} / \mathrm{kgDM}$ ) concentrations (Suttle \& McLauchlan 1976).

Clinical symptoms of $\mathrm{Cu}$ deficiency in cattle are usually manifest during spring. Molybdenum has been widely reported to be one of the more seasonal herbage elements, rising sharply in spring (Cornforth 1984). It was therefore hypothesised that increases in Mo herbage in spring may reduce liver $\mathrm{Cu}$ concentrations in cattle and trigger outbreaks of clinical $\mathrm{Cu}$ deficiency. It was the objective of this experiment to measure seasonal relationships of herbage elements $(\mathrm{Cu}, \mathrm{Mo}, \mathrm{S}, \mathrm{Fe})$, pasture growth, and soil moisture and to determine their relationships with liver $\mathrm{Cu}$ concentration in weaner heifers and breeding cows on commercial farms in the Wairoa region.

\section{Materials and methods}

\section{Farms and animals}

Seven farms in the Wairoa district were selected to encompass both high and low Mo soils. Liver biopsies were collected (Wairoa Veterinary Services), at 2-4 monthly intervals (within constraints of a wet winter in 1997 and a drought in 1998), from weaner heifers ( $\mathrm{n}=10$ $12)$ and breeding cows $(n=10-12)$. Individually identified cattle were sampled from spring 1996 to spring 
1997 (the average number of samples collected was 2.4 and 3.3 for cows and weaners respectively). A second group was sampled from autumn 1998 to spring 1998 (average number of samples collected was 3.6 for both cows and weaners). The monitor animals were managed with their cohorts under normal farm management practices but without $\mathrm{Cu}$ supplementation. Farm A used $\mathrm{Cu}$ fertiliser $\left.(9 \mathrm{~kg} / \mathrm{ha} \mathrm{CuSO})_{4}\right)$ on 60 ha of the flat areas of the farm at 8 month intervals.

Liver samples were frozen and $\mathrm{Cu}$ concentrations were later determined by inductively coupled plasma (ICP) emission spectrometry (Lee 1983) and for low $\mathrm{Cu}$ concentrations by Zeeman flameless atomic absorption.

\section{Herbage and soil}

Three cages were sited within a permanent $5 \mathrm{~m}^{2}$ monitor site on each farm. At 1 month intervals, herbage from within and outside the cage, and standing herbage offered to the breeding cows and weaner cattle (from the paddocks they were presently grazing), was clipped to $2 \mathrm{~cm}$ using electric hand shears. Cages were resited after herbage collection. Herbage was washed and dried $\left(60^{\circ} \mathrm{C}>24 \mathrm{hrs}\right)$ and herbage mass calculated. Dried washed herbage was sent to a commercial laboratory for measurement of herbage $\mathrm{Cu}, \mathrm{Mo}, \mathrm{S}$ and $\mathrm{Fe}$ concentrations. Herbage collected from both within and outside the cage was subsampled every two to three sample collections and separated into grass, legume, weeds and dead components before drying and weighing. Soil cores ( $75 \mathrm{~mm}$ depth) were collected for gravimetric determination of soil moisture.

\section{Statistics}

Herbage mineral concentrations, soil moisture and pasture growth rates were $\log _{\mathrm{e}}$ transformed before analysis to normalise the data. Least square means and associated $95 \%$ confidence limits of $\log _{e^{-}}$ transformed variables were back-transformed for presentation. Analyses were conducted using the GLM procedure of SAS (SAS 1989), with season and farm treated as fixed effects. Three month inclusive periods were used to define seasons; spring (September to November), summer (December to February), autumn (March to May) and winter (June to August). Associations amongst herbage element concentrations, soil moisture, pasture growth rate and herbage composition variables were analysed by calculation of partial correlations after adjusting for farm and season effects. Analysis of the relationship between liver $\mathrm{Cu}$ concentrations and herbage mineral concentration was performed by pairing liver measurements with herbage data from pasture on which the cattle had been grazing within the 45 day period preceding the liver biopsy. The MIXED procedure of SAS (SAS 1989) was used to produce a reduced model pooling data from both classes of cattle and all farms. Iron and Mo were dropped from the equation because there was no evidence of a significant effect on liver $\mathrm{Cu}$.

\section{Results and discussion}

Herbage minerals, herbage growth and soil moisture were all highly seasonal $(\mathrm{P}<0.001)$ on the fixed herbage sample site. The pattern of seasonal concentrations of herbage $\mathrm{Cu}$ and $\mathrm{S}$ was very similar (Figure 1). Lower concentrations were found during summer but concentrations increased by $30-50 \%$ over autumn and winter (Table 1). Herbage $\mathrm{Fe}$ concentration was also low (mean of $260 \mathrm{mg} / \mathrm{kgDM}$ for 2 years) in summer but $180 \%$ higher in winter presumably due to soil contamination of the herbage. In contrast, mean concentrations of Mo only differed by $18 \%$ between seasons with concentrations being lower in autumn largely due to low levels of Mo in herbage in the autumn of 1998 (Table 1). In association with these lower herbage Mo concentrations, liver $\mathrm{Cu}$ in cows and weaners were 180 and $237 \mu \mathrm{mol} / \mathrm{kgFW}$ respectively higher in the autumn of 1998 compared to that of 1997 (Table 1). Mean herbage Mo concentration by month across farms did show a seasonal trend but this was smaller than the other elements (Figure 1). Increases in herbage Mo were observed on half of the farms between June and December but the timing of such rises was not consistent across farms and years (data not shown). Herbage Mo concentration increased as soil moisture increased in autumn $(\mathrm{r}=0.63, \mathrm{P}<0.01)$ and when the proportion of dead herbage decreased in winter and spring $(\mathrm{P}<0.05)$. Herbage Mo has been

Table 1 Effect of season on herbage minerals (S sulphur; Cu copper; Fe iron; Mo molybdenum) from regrowth cages and liver $\mathrm{Cu}$ concentrations in cows and weaner cattle on seven Wairoa farms in 1997 and 1998.

\begin{tabular}{|c|c|c|c|c|c|c|c|}
\hline \multirow[t]{2}{*}{ Season } & \multirow[t]{2}{*}{ Year } & \multicolumn{4}{|c|}{$\begin{array}{l}\text { Herbage minerals } \\
-\quad \mathrm{g}(\mathrm{mg} / \mathrm{kgDM})\end{array}$} & \multicolumn{2}{|c|}{$\begin{array}{c}\text { Liver Copper } \\
(\mu \mathrm{mol} \mathrm{Cu} / \mathrm{kgFW})\end{array}$} \\
\hline & & S & $\mathrm{Cu}$ & $\mathrm{Fe}$ & Mo & Cows & Weaners \\
\hline Aut & 1997 & 3.5 & 11.1 & 383 & 1.3 & 11 & 12 \\
\hline Aut & 1998 & 3.5 & 11.7 & 470 & 1.0 & 49 & 62 \\
\hline Win & 1997 & 3.5 & 12.6 & 571 & 1.4 & 15 & 44 \\
\hline Win & 1998 & 3.9 & 12.1 & 580 & 1.2 & 32 & 38 \\
\hline Spr & 1997 & 3.1 & 10.5 & 280 & 1.6 & 9 & 42 \\
\hline Spr & 1998 & 3.7 & 10.0 & 282 & 1.1 & 18 & 59 \\
\hline Sum & 1997 & 2.9 & 7.2 & 245 & 1.3 & 20 & 20 \\
\hline Sum & 1998 & 2.6 & 7.9 & 275 & 1.2 & 30 & 28 \\
\hline \multirow{3}{*}{\multicolumn{2}{|c|}{$\begin{array}{l}\text { Season } \\
\text { Season*Year } \\
\text { Month(year) }\end{array}$}} & 0.0001 & 0.0001 & 0.0001 & 0.004 & 0.0001 & 0.0001 \\
\hline & & 0.0001 & 0.0001 & 0.0001 & 0.01 & 0.0001 & 0.0001 \\
\hline & & 0.0001 & 0.0008 & 0.09 & 0.09 & na & na \\
\hline
\end{tabular}


widely reported to be one of the more seasonal herbage elements largely based on studies conducted on peat soils, soils in which herbage Mo was low and where Mo had been applied with fertiliser. This study on soils with high native Mo concentrations suggested that herbage Mo did not show a consistent seasonal trend in the Wairoa environment.

Figure 1 Effect of month on herbage sulphur, copper, molybdenum and iron on a fixed sampling site on seven farms in the Wairoa region.
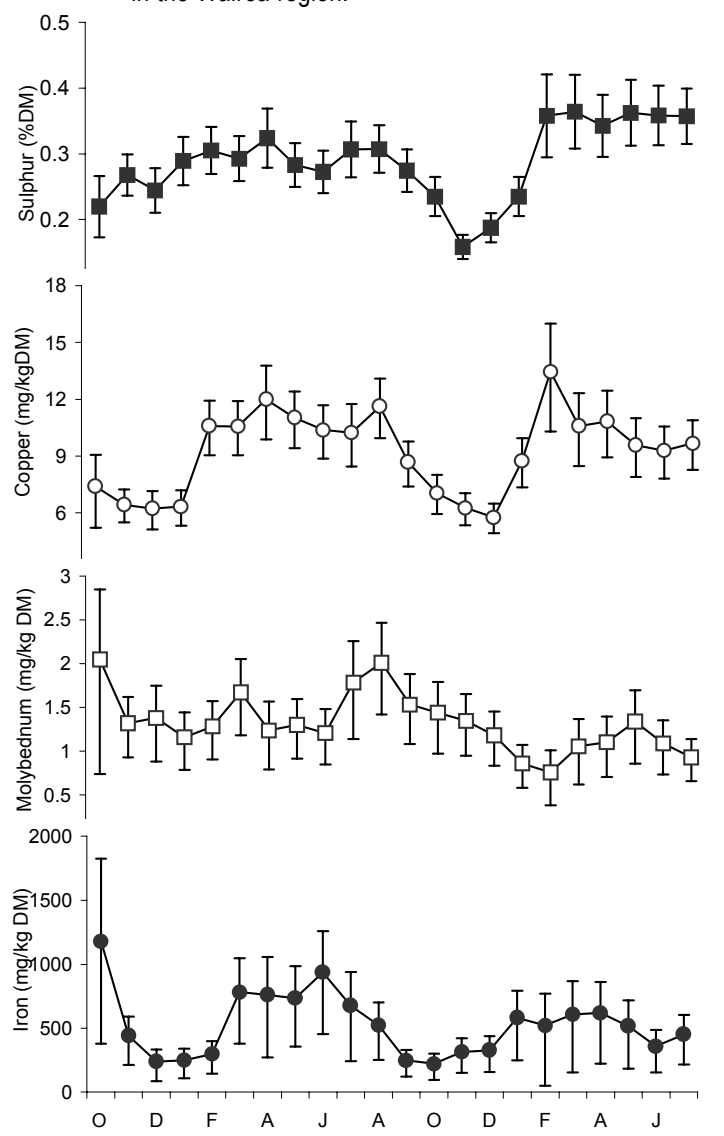

Overall, herbage offered to cattle contained 0.7 to $3.2 \mathrm{mgMo} / \mathrm{kg} \mathrm{DM}$ and $6.6-10.3 \mathrm{mg} \mathrm{Cu} / \mathrm{kgDM}$ (Table 2). Farms B and C, located on Hangaroa soils, and farms $F$ and $G$, located on Tuai soils, had concentrations of $\mathrm{Cu}$ in the herbage sufficiently low to potentially induce direct $\mathrm{Cu}$ deficiencies. Mean farm liver $\mathrm{Cu}$ tended to fall with increasing mean herbage $\mathrm{Mo}$ and decreasing $\mathrm{Cu}$ concentration with the exception of farm A. Six of the seven farms in this study support the findings of Korte (1995) which found that Mo impaired absorption of $\mathrm{Cu}$ in cattle grazing Wairoa pastures with Mo levels as low as $0.5 \mathrm{mg} / \mathrm{kgDM}$, but once herbage Mo rose above $2 \mathrm{mg} / \mathrm{kgDM}$, then the reduction in absorption is not further diminished. Seasonal variations in liver $\mathrm{Cu}$ within farms was positively affected by increasing herbage $\mathrm{Cu}$ concentration and negatively affected by increasing herbage $\mathrm{S}$ concentration. However, this equation only explained $5 \%$ of the variation in cattle liver $\mathrm{Cu}$ concentrations (Korte et al. 1999). Herbage Mo was notably absent from this equation because herbage Mo within a farm was largely constant while liver $\mathrm{Cu}$ concentrations were variable. In addition, it is probable that once herbage Mo increased above $2 \mathrm{mgMo} / \mathrm{kgDM}$ there was enough Mo present in the diet to saturate $\mathrm{Cu}$ thiomolybdates within the gut of cattle. It appears therefore that in Wairoa, seasonal fluctuations in herbage Mo do not drive changes in liver $\mathrm{Cu}$ concentration.

Over the 2 years, $46 \%$ of cows and $32 \%$ of weaners had liver concentrations below the critical reference value for potential deficiency $(<95 \mu \mathrm{mol} \mathrm{Cu} / \mathrm{kgFW})$. The mean liver $\mathrm{Cu}$ concentration was lower $(\mathrm{P}<0.001)$ in cows $(180 \mu \mathrm{mol} \mathrm{Cu} / \mathrm{kgFW})$ than in weaners $(280$ $\mu \mathrm{mol} / \mathrm{kgFW})$. Cows, therefore, should be the first priority for $\mathrm{Cu}$ supplementation. Weaner liver $\mathrm{Cu}$ concentrations were low in summer and autumn (125 $\mu \mathrm{mol} \mathrm{Cu} / \mathrm{kgFW})$ but repleted over the winter and spring seasons (195 and $238 \mu \mathrm{mol} \mathrm{Cu/kgFW}$ respectively). This repletion/depletion cycle in weaners largely follows the seasonal changes in herbage $\mathrm{Cu}$ concentration. In

Table 2 Effect of farm on mineral concentrations in herbage offered to cattle and on liver copper concentration (cows and weaners combined) from 1996 to 1998 for seven farms in the Wairoa district.

\begin{tabular}{|c|c|c|c|c|c|c|c|c|}
\hline \multirow{2}{*}{$\begin{array}{c}\text { Mineral } \\
\text { concentrations }\end{array}$} & \multirow{2}{*}{$E$} & \multirow[b]{2}{*}{$\mathrm{D}$} & \multirow[b]{2}{*}{$A^{1}$} & \multirow[b]{2}{*}{ G } & Farms & \multirow[b]{2}{*}{ C } & \multirow[b]{2}{*}{ B } & \multirow[b]{2}{*}{$\mathrm{P}<$} \\
\hline & & & & & $\mathrm{F}$ & & & \\
\hline \multicolumn{9}{|c|}{ Herbage (mg/kgDM) } \\
\hline Molybdenum & $0.7^{\mathrm{e}}$ & $1.2^{\mathrm{d}}$ & $1.2^{\mathrm{d}}$ & $1.8^{\mathrm{c}}$ & $2.2^{\mathrm{b}}$ & $2.6^{\mathrm{b}}$ & $3.2^{\mathrm{a}}$ & 0.0001 \\
\hline Copper & $8.7^{c}$ & $9.8^{\mathrm{ab}}$ & $10.3^{a}$ & $6.6^{\mathrm{e}}$ & $8.4^{\mathrm{c}}$ & $7.6^{d}$ & $7.3^{d}$ & 0.0001 \\
\hline Sulphur & $3.0^{a}$ & $2.8^{a}$ & $2.9^{a}$ & $2.7^{a}$ & $2.4^{a b}$ & $2.2^{\mathrm{b}}$ & $2.0^{b}$ & 0.0001 \\
\hline Iron & $380^{c}$ & $600^{e}$ & $580^{e}$ & $280^{d}$ & $230^{d}$ & $400^{b}$ & $580^{e}$ & 0.0001 \\
\hline \multicolumn{9}{|c|}{ Liver $(\mu \mathrm{mol} / \mathrm{kgFW})$} \\
\hline Copper & $200^{e}$ & $160^{a b}$ & $90^{c}$ & $160^{a b}$ & $120^{b}$ & $110^{b c}$ & $110^{b c}$ & 0.0001 \\
\hline
\end{tabular}

$1 \quad$ Uses Cu fertilisers

abcde Different superscripts within the row indicate that the means differ significantly at $P<0.05$ 
contrast, cows had the highest concentrations of $\mathrm{Cu}$ in their livers in summer $(147 \mu \mathrm{mol} \mathrm{Cu} / \mathrm{kgFW})$ but these fell steadily over winter to reach low $(62 \mu \mathrm{mol} \mathrm{Cu} /$ $\mathrm{kgFW}$ ) levels in spring before calving when the cow has a high demand for $\mathrm{Cu}$. By late pregnancy many of the non $\mathrm{Cu}$ supplemented cows in this study were classified as being deficient based on their liver $\mathrm{Cu}$ concentrations but these cows did not manifest clinical symptoms. There is a gap in our knowledge regarding the factors which trigger the onset of clinical $\mathrm{Cu}$ deficiency in cows and weaners with marginal liver $\mathrm{Cu}$ reserves.

\section{Recommendations}

It is recommended that on farms where clinical $\mathrm{Cu}$ deficiencies have been previously observed, that cows grazing pastures with more than moderate herbage Mo $(>0.7 \mathrm{mg} \mathrm{Mo} / \mathrm{kg} \mathrm{DM})$ in autumn be routinely directly supplemented with $\mathrm{Cu}$ in late autumn/winter to ensure adequate liver stores to meet the high demands for $\mathrm{Cu}$ in late pregnancy and the subsequent lactation. Treatment of the breeding cow should also increase liver $\mathrm{Cu}$ concentrations in calves at birth and possibly in calves at weaning. The effectiveness of the supplementation regimen can be monitored by liver biopsy. Young cattle on farms with a history of $\mathrm{Cu}$ deficiency in young cattle and/or herbage with high Mo concentrations ( $>2 \mathrm{mg} / \mathrm{kg} \mathrm{DM}$ ), should be supplemented with $\mathrm{Cu}$ in the spring-summer period based on measured liver $\mathrm{Cu}$ levels.

\section{Conclusions}

In Wairoa, herbage Mo concentrations are less seasonal than herbage concentrations of $\mathrm{Fe}, \mathrm{S}$ or $\mathrm{Cu}$. Seasonal changes in cattle liver $\mathrm{Cu}$ concentrations within a farm are more related to physiological demand and herbage $\mathrm{Cu}$ and $\mathrm{S}$ concentrations than fluctuations in herbage Mo. However liver $\mathrm{Cu}$ concentrations fell as herbage Mo concentrations increased from 0.7 to a plateau of over $2 \mathrm{mgMo} / \mathrm{kgDM}$.

\section{ACKNOWLEDGEMENTS}

This project was funded by Meat New Zealand (94 PR 135/1.5). The authors express our profound thanks to the farmers who participated in this study and to John Rounce, Fiona Clarke, Wilhelmina Martin for carrying out the liver $\mathrm{Cu}$ analyses.

\section{REFERENCES}

Korte, C.J.; Smith, D.R.; Deaker, J.M.; Scotland, T.; Willimont, M. 1995. Copper and sulphur deficiencies and interactions with other factors in the Wairoa Region. Survey report for Meat New Zealand, Project Number: 94 PR 135/1.5.

Korte, C.J.; Smith, D.; Moffat, C.; Dowling, A.; Litherland, A.J.; Lee, J.; Lambert, M.G. 1999. Copper and sulphur deficiencies and interactions with other factors in the Wairoa region. Report for Meat New Zealand, Project Number: 94 PR 135/ 1.5.

Lee, J. 1983. Calcium matrix effects in multi-element analysis of animal bone by inductively-coupled plasma emission spectrometry. Analytica-ChimicaActa 152: 141-147.

Cornforth, I.S. 1984. Mineral nutrients in pasture species. Proceedings of the New Zealand Society of Animal Production 44: 135-137.

Grace, N.D.; Rounce, J.R.; Knowles, S.; Lee, J. 1997. Changing dietary $\mathrm{S}$ intakes and the $\mathrm{Cu}$ status of grazing lambs. New Zealand journal of agricultural science 40: 329-334.

Phillippo, M.; Humphries, W.R.; Garthwaite, P.H. 1987. The effect of dietary molybdenum and iron on copper status and growth in cattle. Journal of agricultural science 109: 315-320.

Suttle, N.F.; McLauchlan, M. 1976. Predicting the effects of dietary molybdenum and sulphur on the availability of copper to ruminants. Proceedings of the Nutrition Society 35: 1, 22A-23A.

SAS Institute. 1989. SAS user's guide; statistics. Version 6. Cary, NC. 